\title{
IMPACT OF BIOLOGICAL WATER-BASED FERTILISERS UPON SOIL FERTILITY
}

\author{
Valentyna Krutyakova ${ }^{1}$, Nina Pyliak ${ }^{1}$, Olena Nikipelova ${ }^{1}$, Volodymyr Bulgakov $^{2}$, Adolfs Rucins ${ }^{3}$ \\ ${ }^{1}$ Engineering and Technology Institute "Biotechnica", Ukraine; \\ ${ }^{2}$ National University of Life and Environmental Sciences of Ukraine, Ukraine; \\ ${ }^{3}$ Latvia University of Life Sciences and Technologies, Latvia \\ adolfs.rucins@1lu.lv
}

\begin{abstract}
Methods have been investigated for increasing soil fertility, using new biofertilisers, created on the basis of two sewage sludge (SS) biological treatment plants with the participation of an active strain of phosphatemobilising microorganisms. To create composts (biofertilisers), sewage sludge (after 3 years of storage on the sludge areas) was used with fillers (winter wheat straw and sunflower seed husks) in a ratio of $5 \mathrm{~kg}$ of SS: $5 \mathrm{~kg}$ of the organic filler and a suspension of microbacterium barkeri at the rate of $10 \%$ of the total mass of compost. The obtained results of determination of the biological activity of the soil according to the decomposition degree of the flax fabric showed an increase in the microbiological activity when new biofertilisers were introduced. In the rhizosphere soil the amount of microorganisms of various ecological and trophic groups was studied. The obtained results indicate a positive effect of the use of new biofertilisers contributing to an increase in the biological activity of the soil.
\end{abstract}

Keywords: sewage, sludge, microorganisms, biofertilisers, rhizosphere, organic farming.

\section{Introduction}

Increasing the productivity of agriculture, based on the restoration of the soil fertility, and their rational use is an important and urgent task of modern agriculture. Rational methods of the soil management should ensure economically and environmentally stable yields that can be achieved only by maintaining or restoring the soil fertility $[1 ; 2]$. In order to obtain high yields of agricultural crops, it is necessary to create favourable conditions in the soil for the growth and development of plants, which is mainly achieved through the use of organic and mineral fertilisers. The development of modern fertilisation systems provides for the fullest possible satisfaction of the needs of plants in the elements of mineral nutrition. Introduction of the required amount of fertilisers improves the physicochemical properties of soils, promotes the accumulation of nutrients [3;4].

Investigations have shown that the use of organic fertilisers significantly increases the microbial biomass of the soil and the activity of the soil enzymes, while the inorganic fertilisers have a relatively smaller effect [5]. The organic fertilisers improve the physicochemical, chemical and biological properties of soils: the absorption capacity, the soil buffering capacity, the humus content increase, as a result of which its structure, water-air and thermal conditions, etc. are improved.

At present there have been created and industrially produced microbiological preparations based on the amount of the soil bacteria that can significantly improve the supply of the plants with nutrients [68]. In recent decades in a number of Eastern European countries there has been a decrease in the production of organic fertilisers of the livestock origin and, as a result, deterioration of the soil fertility and decrease in agricultural productivity. This situation has led to the search for new types of fertilisation resources. The attention of the scientific and technical community was directed to the local raw materials, namely, to the sewage sludge (SS). According to the European Commission report, published in 2010, 39\% of the sewage sludge produced in the EU is used in agriculture [9]. The composition of the urban wastewater and sewage sludge reflects the use and distribution of elements and pollutants in society. In Sweden, the official statistics show that concentrations of toxic metals in the urban wastewater sludge have declined steadily by up to $90 \%$ since the 1970 s, thanks to environmental programs and legal restrictions on metals in the sediment and the soil. Recycling of the organic waste from the Swedish cities for the arable land is still limited to about $20 \%$ of the total waste generated [10].

The results of studies of the compost obtained from agricultural waste and sewage sludge have shown compliance with the quality criteria for the use in agriculture [11]. In the results using of sludge is presented in a mixture with food waste of the plant origin in a ratio of 1: 1, and the introduction of a starter culture of thermophilic heterotrophic bacilli as a fertiliser after its incubation for 12 days at a temperature of $50{ }^{\circ} \mathrm{C}$, and a humidity of $80 \%$. When the sludge was introduced into the soil, a significant increase in the plant productivity (tomatoes) was observed. One of the perspective areas for the use of the sewage sludge is bioconversion of organogenic waste - the production of available organic raw 
materials (compost) with the participation of phosphate-mobilising microorganisms. To increase the carbon content in the compost mass during the composting of the sewage sludge, special additives fillers are used [12]. Phosphorus is an important nutrient for the plants, contributing to their growth and development. The lack of phosphorus in the soil inhibits the growth and development of the plants; it decreases the efficiency of photosynthesis and the ability of perennial legumes to fix molecular nitrogen from the atmosphere. It is known [13] that concentration of the available phosphorus in the soil is always low throughout the continuous process of its absorption by the plants. The soil microbiota takes an active part in the mobilisation of sparingly soluble phosphates; it has a positive impact on plants, improving their phosphorus nutrition, growth, development and productivity. Therefore, the phosphate-mobilising microorganisms can become one of the components of bioorganic fertilisers.

The purpose of the research is to study ways how to increase the soil fertility using new biofertilisers, based on sewage sludge from biological treatment plants.

\section{Materials and methods}

As the object of the research biofertilisers were used, based on sewage sludge from two biological treatment plants, located in the south of Ukraine, with various fillers, with the participation of an active strain of microorganisms having phosphate-mobilising properties.

The taxonomic status of a strain with phosphate-mobilising properties was determined from the composition of cellular acid lipids on the Agilent 7890 gas chromatograph with an ULTRA-2 capillary column and a flame ionisation detector. Due to the absence of virulence the strain of Microbacterium barkeri is assigned to the IV hazard class. By the composition the wastewater sludge from these biological treatment plants meets the requirements of regulatory documents [14-15], which apply to fertilisers of such origin.

Technological stages of creating biofertilisers, based on sewage sludge with various fillers with participation of an active strain with phosphate-mobilising properties, have been worked out.

The production of biofertilisers includes: composting the sewage sludge with vegetable fillers, composting with participation of the phosphate-mobilising bacterium Microbacterium barkeri LP-1 (M. b.). Composting involves the following successive steps. Namely: after three years of storage on silt fields, the sewage sludge with vegetative fillers (winter wheat straw or sunflower seed husks) in a ratio of 1: 1 is laid in layers. The bottom and top layers are vegetable fillers. Composting continues for 2 months with periodic mixing of the compost mass once every 2 - 3 weeks, which allows saturation of the substrate with oxygen. This is due to the following reasons: inhibition of the development of the introduced bacterial strain with ammonia, which is formed during the intense decomposition of nitrogen compounds; a decrease in the provision of the introduced aerobic microorganisms with oxygen, which is due to the saturation of the substrate with carbon dioxide released during the mineralisation of the organic substances; by heating the substrate to a temperature from $60{ }^{\circ} \mathrm{C}$ to $70{ }^{\circ} \mathrm{C}$, which reduces the vital activity of the mesophilic microorganisms.

The suspension of Microbacterium barkeri LP-1, the bacterial titre of which is $2 \cdot 10^{9} \mathrm{CFU}$, is added to the substrate at the rate of $10 \%$ of the total mass of the compost with the irrigation water. This ensures even dispersion of bacteria in the substrate. Application of the strain Microbacterium barkeri LP-1, the metabolic products of which are capable of dissolving mineral and organic forms of phosphorus, provides at the final stage of the technological process an increased content of water-soluble forms of phosphorus in bioorganic fertilisers with various fillers.

A prerequisite for efficient composting is maintaining the moisture content of the substrate at $70 \%$ $-80 \%$. A decrease or increase in the moisture content in the compost leads to incomplete processing of the organic matter and a decrease in the quality of the compost. The moisture content in the biofertiliser samples was determined by the classical gravimetric method, which consists in drying the sample in a thermostat at $105^{\circ} \mathrm{C}$ to a constant value of the substrate. The moisture control took place from the first day after laying the compost - once a week, for eight weeks, and the temperature control - in the same period, starting from the third day -2 times a week. The composting process continued until the straw was decomposed in the substrate, and this indicated the final stage of composting. The maturation of the compost with fillers took place for 4 months. 
The biological activity of the soil when using biofertilisers, based on the sewage sludge, was determined by the application method [16]. The application method is simple and, nevertheless, informative enough, which makes it possible to determine the intensity of the course of microbiological processes in vivo. The biological activity of the soil with the use of new biofertilisers was studied in a field experiment with corn. For this purpose, an experiment was made on the ordinary medium-humus (chernozem), which is characterised by the following agrochemical indicators: the humus content $3.67 \%$; the mobile forms of nitrogen $-14.2 \mathrm{mg} \cdot \mathrm{kg}^{-1}$; phosphorus $-52.4 \mathrm{mg} \cdot \mathrm{kg}^{-1}$; potassium $601.2 \mathrm{mg} \cdot \mathrm{kg}^{-1}, \mathrm{pH}$ (aqueous) -7.4 units $\mathrm{pH}$.

The variants of the experience: 1 - without fertilisation (control); 2 - the wastewater sludge SBO 1 at a dose of $\mathrm{N}_{\text {tot. }} 100 \mathrm{~kg} \cdot \mathrm{ha}^{-1} ; 3$ - the wastewater sludge SBO 2 at a dose of $\mathrm{N}_{\text {tot. }} 100 \mathrm{~kg} \cdot \mathrm{ha}^{-1} ; 4$ - the compost SBO 1 in a dose of $\mathrm{N}_{\text {tot. }} 100 \mathrm{~kg} \cdot \mathrm{ha}^{-1}$ with winter wheat straw and Microbacterium barkeri LP1 (M. b.); 5 - the compost SBO 1 in a dose of $\mathrm{N}_{\text {tot. }} 100 \mathrm{~kg}^{\circ} \mathrm{ha}^{-1}$ with the hulls of the sunflower seeds and Microbacterium barkeri LP-1; 6 - the compost SBO 2 in a dose of $\mathrm{N}_{\text {tot. }} 100 \mathrm{~kg} \mathrm{ha}^{-1}$ with winter wheat straw and Microbacterium barkeri LP-1; 7 - the compost SBO 2 in a dose of $\mathrm{N}_{\text {tot. }} 100 \mathrm{~kg} \mathrm{ha}^{-1}$ with the hulls of the sunflower seeds and Microbacterium barkeri LP-1.

The area of the sown plot is $527 \mathrm{~m}^{2}$ (the plot size $-17 \mathrm{~m} \mathrm{x} 31 \mathrm{~m}$ ), the accounted area $-392 \mathrm{~m}^{2}$ (plot size $-14 \mathrm{~m} \times 28 \mathrm{~m}$ ), the variants in the experiment with their randomised placement were repeated six times. The crop in the experiment: corn for grain (mid-season hybrid FAO 400). The introduction doses of the native sewage sludge and fertilisers, based on them, into the soil were levelled according to their total nitrogen content. In the experiment fertilisers were applied for fall ploughing randomly (all over the place) on the plots for the grain corn. Tillage is commonly accepted (ploughing to a depth of 20$30 \mathrm{~cm}$, the early spring harrowing). The corn (maize) was sown in the first ten days of May when a stable temperature (more than $10^{\circ} \mathrm{C}$ ) came. The plant placement scheme $-40-45 \cdot 10^{3}$ pieces ha ${ }^{-1}$. During the vegetation period manual subsidence was carried out.

In order to determine the intensity of cellulose decomposition when using biofertilisers, based on sewage sludge, a linen cloth, $10 \mathrm{~cm}$ wide, ironed with a hot iron, was taken, at the length-height of the arable layer of the studied soil $(20 \mathrm{~cm})$ was attached to a polymer film. A fresh cut of the soil was made and pressed the canvas against its vertical, well-cleaned wall. On the other hand, the polyethylene was pressed down with soil, and the incision was filled. The cloth was installed so that the top of the cloth was 3-5 $\mathrm{cm}$ below the soil surface.

After two months the cloths were carefully removed, washed from soil and half-life products, dried and weighed. The weight loss was used to judge the intensity of the fibre destruction process.

In the rhizosphere soil the amount of microorganisms - representatives of various ecological and trophic groups - was investigated according to generally accepted microbiological methods [16]. The method of inoculation of suspensions was used in appropriate dilutions on the selective nutrient media. There was studied the amount of bacteria assimilating the mineral nitrogen compounds and streptomycetes - on starch-ammonia agar [6], the amount of bacteria assimilating the organic nitrogen compounds - on meat-peptone agar, the phosphate-mobilising bacteria - on Muromtsev's medium, the microscopic fungi - on Sabouraud's medium, determination of the number of spore forms of the microorganisms was carried out on mesopatamia agar + wort agar, oligotrophs - on starvation agar. The assessment of the parameters of the number of microbial groups with different taxonomic status is based on a comparative method, according to which the indicators of the amount of microorganisms in the new biofertiliser, based on the sewage sludge, were compared with the indicators of the amount of microorganisms in the control group.

The statistical calculation of the results was performed using the variance (dispersion) [17].

\section{Results and discussion}

The results of the investigations of WWS by their quality, safety for the environment, ecological and microbiological assessment of the WWS and the feasibility of using them as fertilisers have been highlighted by us in the previous articles [18]. It has been established that these WWS are characterised by a number of positive agronomic characteristics, satisfactory sanitary and microbiological indicators; phytotoxicity in relation to higher plants was not found. According to the complex of microbiological indicators these substrates are acceptable for the development of microorganisms that consume organic 
and mineral nitrogen compounds, streptomycetes, phosphate-mobilizing and spore microorganisms. When determining the functional orientation of microbiological processes, the investigated substrates are characterised by a high supply of nutrients; the parameters of the mineralisation-immobilisation coefficient indicate the predominance of the synthesis processes over the destruction of the organic matter. According to the research results these WWS are suitable both for direct use as fertilisers and for creating composts on their basis for use in agriculture. The studies in composts (new biofertilisers), based on sewage sludge, of a number of microorganisms - representatives of various ecological and trophic groups, showed that application of biofertilisers, based on sewage sludge, will have a positive effect on the functioning of agrocenoses [19] ). The results of determining the biological activity of the soil according to the degree of decomposition of the linen cloth showed an increase in the microbiological activity when applying biofertilisers based on the sewage sludge. However, the intensity of decomposition for the variants of the experiment differed, but not significantly (Table 1, Fig. 1).

Table 1

Determination of the soil biological activity

\begin{tabular}{|l|c|c|c|c|}
\hline Variant of the experiment & $\begin{array}{c}\text { Mass of the } \\
\text { cloth at the } \\
\text { beginning of the } \\
\text { experiment, g }\end{array}$ & $\begin{array}{c}\text { Mass of the } \\
\text { cloth at the } \\
\text { end of the } \\
\text { experiment, g }\end{array}$ & $\begin{array}{c}\text { \% of } \\
\text { decompo } \\
\text { sition of } \\
\text { the cloth }\end{array}$ & $\begin{array}{c}\text { " " or "-" } \\
\text { to the } \\
\text { reference, } \\
\text { \% }\end{array}$ \\
\hline Without a fertiliser (reference) & 5.31 & 4.62 & 13.0 & - \\
\hline Sewage sludge of native SBO 1 & 5.18 & 4.10 & 20.1 & +7.1 \\
\hline Sewage sludge of native SBO 2 & 5.26 & 4.26 & 19.0 & +6.0 \\
\hline Compost SBO 1 + straw + M. $b$. & 5.22 & 3.96 & 24.1 & +11.1 \\
\hline Compost SBO 1 + husks + M. $b$. & 5.14 & 3.87 & 24.7 & +11.7 \\
\hline Compost SBO 2 + straw + M. $b$. & 5.21 & 3.89 & 25.3 & +12.3 \\
\hline Compost SBO 2 + husks + M. $b$. & 5.19 & 3.97 & 23.5 & +10.5 \\
\hline
\end{tabular}

As show (Fig. 1) 1 - the control, in the central part there are visible traces of metabolic products of microorganisms; 2 - the native wastewater sludge SBO 1 - to the left of the centre of the tissue there are visible insignificant violations of the structure of the linen cloth, as well as more pronounced traces of metabolic products of microorganisms; 3 - the native wastewater sludge SBO 2 demonstrating the tissue destruction in the lower right corner, and again, the products of metabolism of microorganisms; 4 - the compost SBO 1 with the winter wheat straw and a phosphate-mobilising strain M. b. - in the left central part of the tissue a more pronounced violation of its structure is noted in comparison with violations of the right lower part; 5 - the compost SBO 1 with the hulls of the sunflower seeds and a phosphate-mobilizing strain M. b. - there is a stronger destruction of tissues in the lower and right parts of it, as well as metabolic products of microorganisms. Thus, it is evident that, in addition to the metabolic products of microorganisms, there is a more pronounced violation of the structure of the linen tissue; this means that the introduction of additional organic matter contained in the composts, based on sewage sludge, stimulates the development of various groups of microorganisms; 6 - the compost SBO 2 with winter wheat straw and a phosphate-mobilising strain M. b. - demonstrates the greatest destruction of the linen cloth, especially in its lower part; 7 - the compost SBO 2 with the sunflower seed husk and an addition of phosphate-mobilising strain M. b. - also shows visible large destruction of tissue in the lower part of the picture.

During the research period decomposition of the linen cloth was determined as the highest, when a fertiliser was applied (the sewage sludge SBO $2+$ straw + M. b.), which in a 0-20 cm layer was $-25.3 \%$ and which was by $12.3 \%$ higher in comparison with the reference. When introducing a fertiliser on the basis of (the sewage sludge SBO $2+$ husk + M. b.), the degree of decomposition of the linen cloth was $23.5 \%$, which is by $10.5 \%$ higher in comparison with the reference. When introducing a fertiliser, based on the waste water sludge SBO 1 with straw and husk, the degree of decomposition of the linen cloth was almost the same and amounted to $24.1 \%$ and $24.7 \%$, which is by $11.1 \%$ and $11.7 \%$, respectively, higher than in the reference. The rate of decomposition of the linen cloth is highly dependent on the weather conditions. 


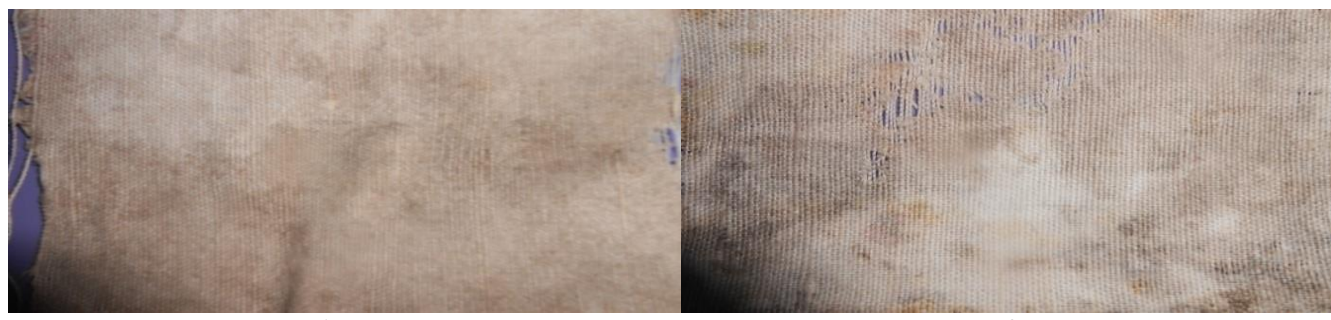

1 2
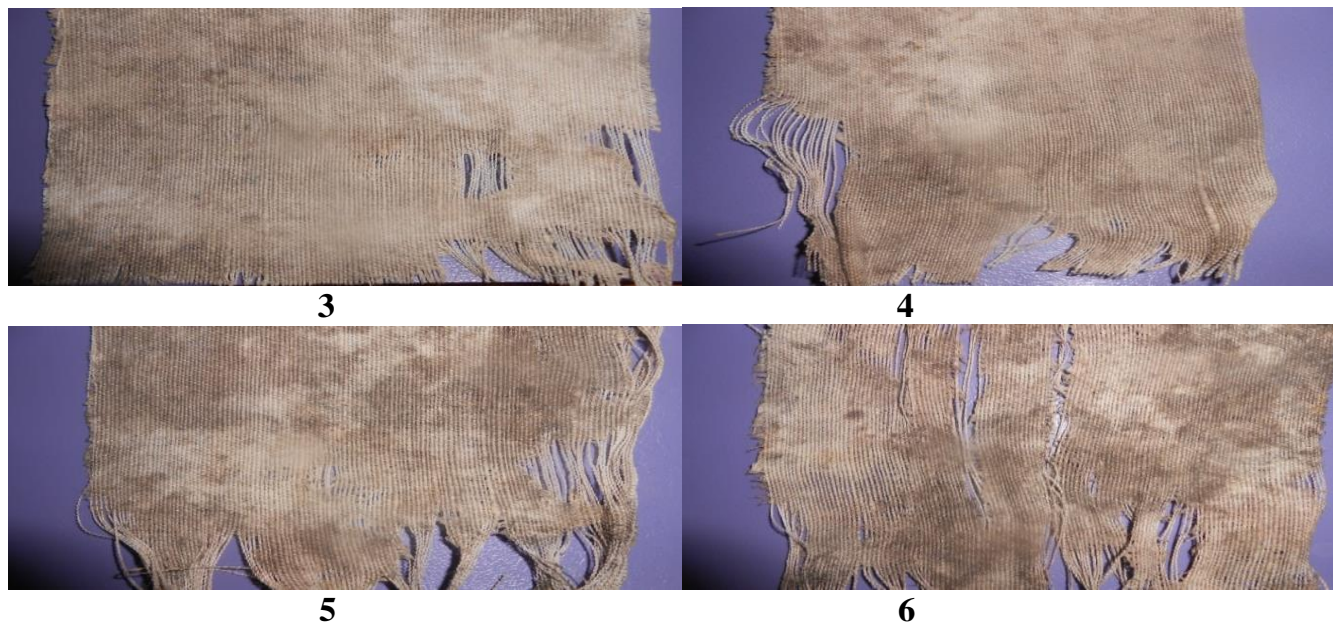

5

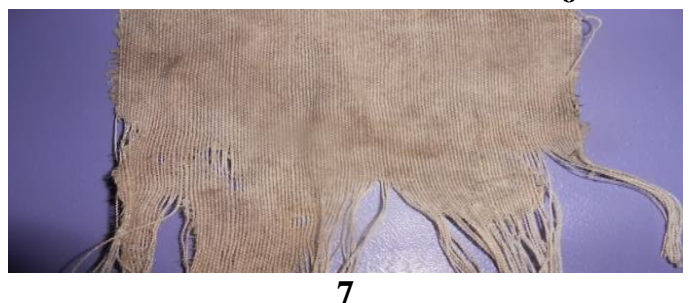

Fig. 1. Intensity of decomposition of the linen cloth when determining the biological activity of soil, variants: 1 - without fertilisation (control); 2 - with the wastewater sludge SBO $1 ; 3$-with the wastewater sludge SBO 2; 4 - with the compost SBO 1;5 - the compost SBO 1; 6 - with the compost SBO 2; 7 - witht he compost SBO

With a sufficient amount of precipitation the processes of decomposition of the linen cloth are usually more intense. However, the year 2019 turned out to be very dry, the amount of microbial communities with different taxonomic status decreased, and therefore the decomposition of linen tissue somewhat slowed down. Similar results were obtained by the authors [20] - in the dry summer period of 2013 the intensity of the microflora development, on the whole, was much lower, yet this did not prevent the dependence of the biological activity and the number of microorganisms on fertilisation. Since the biological activity of the soil is a total indicator that includes the number of microorganisms of various ecological and trophic groups, their content in the rhizosphere soil was studied (Table 2). When conducting microbiological investigations of the rhizosphere of the corn, it was found that the ratio and amount of microorganisms of various physiological groups depend on the application of fertilisers.

In the rhizosphere soil of corn, the number of the following groups of microorganisms has been determined: bacteria that predominantly assimilate mineral and organic nitrogen compounds, streptomycetes, microscopic fungi, spore and phosphate-mobilising microorganisms. The quantitative composition of microorganisms of the physiological groups is an integral characteristic of the analysis of the functioning of the soil microbiota and it is used as an indicator in determining its biological activity. The microbiological investigations of the rhizosphere of corn (maize) in the phase of full grain ripeness have shown that the ratio and amount of microorganisms of various physiological groups depend on the introduction of organic substrates. Thus, the amount of microorganisms that use the organic nitrogen compounds was quite high and ranged from $120.3 \pm 4.6$ million CFU. $\mathrm{g}^{-1}$ soil up to $250.3 \pm 7.2$ million $\mathrm{CFU} \cdot \mathrm{g}^{-1}$ soil. In addition, the greatest amount of ammonifiers $\mathrm{CFU} \cdot \mathrm{g}^{-1}$ soil up to 
$250.3 \pm 7.2$ million CFU $\cdot \mathrm{g}^{-1}$ soil was found when using biofertilisers, based on compost-based SBO $1+$ straw + M.b., indicating the activation of microbiota in the ordinary a fertile black soil rich in humus (chernozem) in the presence of a nutrient substrate in the form of organic matter (biofertilizers).

Table 2

Parameters of multitude of ecological and trophic groups of microorganisms in the rhizosphere of the maize plants with different fertilisation systems in the phase of full grain ripeness

\begin{tabular}{|c|c|c|c|c|c|c|}
\hline \multirow[b]{2}{*}{$\begin{array}{l}\text { Variant of the } \\
\text { experiment }\end{array}$} & \multicolumn{6}{|c|}{ Multitude of groups of microorganisms } \\
\hline & $\begin{array}{c}\text { Phosphate } \\
\text { mobilisers, } \\
\text { million } \\
\text { CFU } \cdot \mathrm{g}^{-1} \\
\text { soil }\end{array}$ & $\begin{array}{c}\text { Ammonifie } \\
\text { r, } \\
\text { million } \\
\text { CFU } \cdot \mathrm{g}^{-1} \\
\text { soil }\end{array}$ & $\begin{array}{c}\text { Nitrifier } \\
\text { s, } \\
\text { million } \\
\mathrm{CFU} \cdot \mathrm{g}^{-1} \\
\text { soil }\end{array}$ & $\begin{array}{c}\text { Strepto- } \\
\text { mycetes, } \\
\text { million } \\
\mathrm{CFU} \cdot \mathrm{g}^{-1} \\
\text { soil }\end{array}$ & $\begin{array}{c}\text { Sporo- } \\
\text { phytes } \\
\text { million } \\
\mathrm{CFU} \cdot \mathrm{g}^{-1} \\
\text { soil }\end{array}$ & $\begin{array}{c}\text { Micro- } \\
\text { mycetes } \\
\text { thousand } \\
\mathrm{CFU} \cdot \mathrm{g}^{-1} \\
\text { soil }\end{array}$ \\
\hline $\begin{array}{r}\text { No fertiliser } \\
\text { (referenc }\end{array}$ & $15.7 \pm 0.9$ & $120.3 \pm 4$ & $5.0 \pm 2.1$ & $2.3 \pm 1.4$ & $62.0 \pm 1.1$ & $3.4 \pm 2.3$ \\
\hline OSV native SBO 1 & $13.3 \pm 1.2$ & $166.6 \pm 4.8$ & $7.7 \pm 2.9$ & $5.0 \pm 1$. & $79.0 \pm 2.9$ & $3.6 \pm 0.7$ \\
\hline OSV native SBO 2 & $6.0 \pm 1.1$ & $145.3 \pm 6.9$ & $6.0 \pm 2.0$ & $3.0 \pm 1.0$ & $69.0 \pm 0.9$ & $5.3 \pm 0.7$ \\
\hline $\begin{array}{r}\text { Comt } \\
1+\text { str: }\end{array}$ & $40.0 \pm 0.6$ & $250.3 \pm 7.2$ & $7.0 \pm 1.1$ & $5.0 \pm 1.1$ & $90.7 \pm 2.9$ & $4.7 \pm 0.7$ \\
\hline $\begin{array}{l}\text { Comp } \\
1+\text { hu }\end{array}$ & $33.7 \pm 2.0$ & $211.6 \pm 6.0$ & $6.7 \pm 1.7$ & $7.0 \pm 1.1$ & $83.0 \pm 4.0$ & $4.0 \pm 2.0$ \\
\hline $\begin{array}{c}\text { Compost SBO } \\
2+\text { straw }+ \text { M. b. }\end{array}$ & $36.0 \pm 0.0$ & $226.0 \pm 5.2$ & $6.3 \pm 2.3$ & $5.4 \pm 1.1$ & $81.3 \pm 0.7$ & $4.6 \pm 1.3$ \\
\hline $\begin{array}{c}\text { Compost SBO } \\
2+\text { husk + M. b. }\end{array}$ & $31.0 \pm 1.0$ & $196.3 \pm 6.7$ & $6.6 \pm 1.7$ & $4.7 \pm 0.6$ & $73.3 \pm 2.3$ & $5.0 \pm 1.0$ \\
\hline $\mathrm{LCD}_{0.5}$ & 1.96 & 5.01 & 7.11 & 3.82 & 5.59 & 4.40 \\
\hline
\end{tabular}

The amount of microorganisms that assimilate mineral nitrogen and participate in the decomposition of the plant and animal residues in the soil, humus mineralisation, was insignificant in all variants of the experiment, million CFU. $\mathrm{g}^{-1}$ soil - from $5.0 \pm 2.1$ to $7.7 \pm 2.9$.

The amount of bacteria transforming the organic phosphorus compounds was also the highest in the variant $\left(15.7 \pm 0.9\right.$ million $\mathrm{CFU} \cdot \mathrm{g}^{-1}$ soil) with the addition of bioorganic fertilisers: Compost SBO $2+$ straw + M. b. $\quad\left(36.0 \pm 0.0\right.$ million $\mathrm{CFU}^{-1}$ soil $)$ - Compost $\mathrm{SBO} 1+$ straw $+\mathrm{M} . \quad$ b. (40.0 \pm 0.6 million CFU $\cdot \mathrm{g}^{-1}$ soil). The amount of microscopic fungi in the control (reference) variants Compost SBO $1+$ straw + M. b. $\left(40.0 \pm 0.6\right.$ million CFU. ${ }^{-1}$ soil $)$, and in the new types of biofertilisers (Compost SBO $1+$ husk + M. b.: Compost SBO $2+$ husk + M. b. $-4.0 \pm 2.0$ thousand CFU. ${ }^{-1}$ soil: $5.0 \pm 1.0$ thousand $\mathrm{CFU} \cdot \mathrm{g}^{-1}$ soil) did not differ significantly from each other. Consequently, microorganisms that assimilate organic nitrogen compounds are dominant. A fairly high number of spore-forming microorganisms $\left(73.3 \pm 2.3\right.$ million CFU $\cdot \mathrm{g}^{-1}$ soil $-90.7 \pm 2.9$ million CFU $\cdot \mathrm{g}^{-1}$ soil), the presence of which confirms the assumption that the biofertilisers, based on sewage sludge, are favorable for the development of spore microorganisms, since they contain the necessary carbon substrates and associated nitrogenous compounds. As evident from the data of the table, the number of phosphatemobilising microorganisms is a higher order of magnitude when using biofertilisers, based on the sewage sludge, compared to the reference. The number of microorganisms assimilating mineral nitrogen, as well as micromycetes and streptomycetes, was insignificant. The number of oligotrophic microflora, functioning under the conditions of an insignificant content of available carbon-containing compounds in the soil solution, indicates a sufficient amount of nutrients in it.

According to the results of the field investigations, it was found that the use of biofertilisers, based on sewage sludge in the corn cultivation technologies, contributes to an increase in the content of microorganisms of various ecological and trophic groups, and this, in turn, increases the biological activity of the soil and provides an increase in the yield. Similarly, the authors [21] have shown the dependence of the biological activity of soils on the amount of soil microbiota. 


\section{Conclusions}

1. The use of the developed biofertilisers, based on sewage sludge, contributes to utilisation of the sludge accumulated on the sludge beds, and the provision of agriculture with valuable organic fertilisers. The compost, based on sewage sludge from biological treatment plants and fillers in the form of the winter wheat straw and sunflower seed husks in the south of Ukraine, has a positive effect on the quality of biofertilisers and stimulates the development of various groups of microorganisms.

2. In the variant of the experiment "compost SBO $2+$ winter wheat straw + phosphate-mobilising strain $M . b$." according to the degree of decomposition of the linen cloth, an excess of the value of the indicator of the biological activity of the soil in relation to the reference (control) was noted by $12.3 \%$.

3. Application of biofertilisers promotes the development of microorganisms that assimilate organic nitrogen compounds, as well as phosphate-mobilizing and spore microorganisms, the number of which has doubled compared to the reference, which indicates an increase in the biological activity of soils from the use of biofertilizers.

\section{References}

[1] Jurandy E., Bran Nogueira Cardoso E.J., Figueiredo Vasconcellos R.L., Bini D. Soil health: looking for suitable indicators. What should be considered to assess the effects of use and management on soil health? Sci. agric. (Piracicaba, Braz.); Volume 70(4), 2013.

[2] Amir H. N., Mahnaz N., Safora K., Maryam H., Sharareh, M. Sewage sludge composting: quality assessment for agricultural application. Environ Monit Assess, Volume 187 (11), 2015, art. 709.

[3] Vasilenko M.G., Stadnik A.P. Agroekologicheskoye obosnovaniye primeneniya novykh otechestvennykh udobreniy i regulyatorov rosta rasteniy $\mathrm{v}$ agroekosistemakh. (Agroecological substantiation of application of new domestic fertilizers and plant growth regulators in agroecosystems). Vinnytsia: TVORI, 2019, 340 p. (In Ukrainian)

[4] Ramdani N., Hamou A., Lousdad A., Al-Douri Y. Physicochemical characterization of sewage sludge and green waste for agricultural utilization. Environ Technol. 2015, Volume 36.

[5] Ge G., Li Z., Fan F., Chu G., Hou Z., Lian Y. Soil biological activity and their seasonal variations in response to long-term application of organic and inorganic fertilizers. Plant Soil, Volume 326 (1), 2010, pp. 31-44.

[6] Volkogon V.V., Nadkernichnaya A.V., Tokmakova L.M. Eksperimentalnaya gruntovaya mikrobiologiya. (Experimental soil microbiology). Kiyev: Agrarnaya nauka, 2010, pp. 308-382. (In Ukrainian)

[7] Rathinasabapathi B., Liu X., Cao Y., Ma Lena Q. Phosphate-solubilizing Pseudomonads for improving crop plant nutrition and agricultural productivity. Crop Improvement Through Microbial Biotechnology, 2018, pp. 363-372.

[8] Park J., Bolan N., Mallavarapu M., Naidu R. Enhancing the solubility of insoluble phosphorus compounds by phosphate solubilizing bacteria. 19-th World Congres of Soil Science, Brisbane, Australia, 2010, pp. 65-68.

[9] Lamastra L., Susiu N.A., Tresian M. Sewage sludge for substainable agriculture; contaminants contents and potential use as fertilizer. Chemical and Biological Technologies in Agroculture. 2018, Volume 5(1), pp. 1-6.

[10] Kirchmann H., Börjesson G., Kätterer T., Cohen Y. From agricultural use of sewage sludge to nutrient extraction: A soil science outlook. Ambio. 2017 , Volume 46(2), pp. 143-154.

[11] Alvarenga P., Mourinha C., Farto M., Santos T., Palma P., Sengo J., Morais M., Cunha-Queda C. Sewage sludge, compost and other representative organic wastes as agricultural soil amendments. Benefits versus limiting factors. Waste Manage. 2015, Volume 40(3), pp. 44-52.

[12] Gorodnij M.M. Problemy ispolzovanija osadkov stocnyh vod dlja proizvodstva udobreunj (Problems of using sewage sludge for fertiliser production). Vestnik agrarnoj nauki. 2013, No 9, pp. 45-50 (In Russian)

[13] Mahmudul H., Mainul H., Jaime A., Li, H. Regulation of phosphorus uptake and utilization: transitioning from current knowledge to practical strategies. Cellular and Molecular Biology Letters, 2016, pp. 1-9. 
[14] Technological norms 33-3.3-02-99. Tekhnologicheskiye i agroekologicheskiye normativy ispolzovaniya osadkov stochnykh vod gorodskikh ochistnykh sooruzheniy v sel'skom khozyaystve. (Technological and agroecological norms for the use of sewage sludge from urban wastewater treatment plants in agriculture). Kiev, 2000, 38 p. (In Ukrainian)

[15] Standard of Ukraine 7368:2013 Stochnyye vody. Trebovaniya k stochnym vodam i ikh osadkam dlya orosheniya i udobreniya. (Wastewater. Requirements for waste water and their sludge for irrigation and fertilization). Kiev, 2014. 10 p. (In Ukrainian)

[16]Zviaginceva D.G. Metody pochvennoy mikrobiologii i biokhimii. (Methods of soil microbiology and biochemistry). Moscow, MGU, 2010, 224 p. (In Russian)

[17] Dospehov B. Methodology of field experiments. Moscow, 2012, 352 p. (In Russian)

[18] Dyshlyuk V.E., Pilyak N.V., Loban L.L. Agroekologicheskaya harakteristika ta ocenka goroda Odessy na udobreniye (Agroecological characteristics and assessment of the suitability of sewage sludge from the treatment facilities): Mezhved. temat. nauk. sb.. Chernigov. 2017, Vol. 26, pp. 5562 . (In Ukrainian)

[19] Pilyak N.V., Krutyakova V.I., Dyshlyuk V.E. Ekologo-mikrobiologicheskaya harakteristika novyh bioudobreniy na osnove osadkov stochnyh vod ochistitelnyh cooruzheniy g. Odessa. Sbalansirovannoye prirodopolzivaniye (Ecological - microbiological characteristics of new biofertilizers based on sewage sludge from treatment facilities in Odessa. Balanced use of natural resources). 2020, Vol. 2, pp. 93-99 (In Ukrainian).

[20] Snitinskiy V.V., Gabriel A.I., Germanovich O.M. Biologicheskaya aktivnost svetlo-seroy lesnoy poverhnostno-oglesnoy pochvy $\mathrm{v}$ zavisimosti ot antropogennogo vozdeystviya. (Biological activity of light gray forest surface-gley soil depending on anthropogenic impact). Selskohozyaistvennaya mikrobiologiya. 2014, Vol.19 (4), pp. 7-52 (In Russian).

[21] Morugan Alisia, Cerda Artemi Garsia-Orenes, Fuensanta. Geophysical Research Abstracts. Vol. 16, EGU 2014-2499, EGU General Assembly, 2014. 